\title{
LESZEK GAJOS \\ Świadomość religijna i moralna mlodzieży polskiej w badaniach Janusza Mariańskiego. Od opisu do konkluzji teoretycznych
}

Kościól i społeczeństwo zawsze funkcjonują w realnie umiejscowionym kontekście spoleczno-kulturowym. W przeszlości w Polsce dominowal chrześcijański kontekst spoleczno-kulturowy Kościoła. Jego cechą charakterystyczną było przenikanie wartości chrześcijańskich do globalnego spoleczeństwa i kultury oraz silna więź instytucji cywilnych z Kościolem. Ksztaltowala się religijność o dużym uczestnictwie w praktykach religijnych, ale jednocześnie niskiej wiedzy religijnej.

Wspólcześnie nasilają się procesy rozchodzenia się wartości propagowanych przez Kościół i tych, które są atrakcyjne w spoleczeństwie. Procesy te są efektem sekularyzacji, heteronomii losów jednostek, zmian w strukturze spolecznej oraz postępującego pluralizmu.

Wizja Kościola w świadomości spolecznej ulega modyfikacji, jest ona ograniczana do stricte religijnych funkcji. Jeszcze do niedawna, specyfiką formacji religijnej w Polsce bylo to, że katolicyzm był reprezentatywny dla calego spoleczeństwa, niezależnie od tego jak ono bylo wewnętrznie zróżnicowane. Obecnie cecha ta ulega zmianie. Indywidualizacja i pluralizm powoduja, że Kościól utożsamiany do niedawna $z$ narodem, będący symbolem wielofunkcyjnym, pełniący wiele funkcji zastępczych, zmienia swoje znaczenie.

Zmienia się również sposób funkcjonowania parafii, ewoluuje one w kierun$\mathrm{ku}$ zbiorowości, z dominacja struktury statystycznej nie przystosowanej do two- 
rzenia wspólnot parafialnych ${ }^{1}$. W przeszłości aktywność wiernych byla skoncentrowana wokól parafii. Dziś znaczna część aktywności, lącznie z niedzielnymi praktykami religijnymi, realizuje się poza parafią. Ogranicza to funkcje kontrolne i możliwości tworzenia wspólnoty w sensie socjologicznym ${ }^{2}$.

Heteronomia spoleczna powoduje powstawanie alternatywnych (niejednokrotnie konkurencyjnych) systemów wartości, które rywalizują ze sobą. Jak zauważyl K. Mannheim spoleczeństwo nowoczesne jest daleko bardziej plastyczne, albowiem dzięki postępom techniki dysponuje większymi rezerwami ${ }^{3}$. Kościól w tej sytuacji staje się jedną z wielu instytucji ksztaltujacych świadomość ludzi. Nasila się jednak proces oddzielania się instytucji religijnych i świeckich. Kościól zaczyna pelnić węższy, bardziej wyspecjalizowany rodzaj funkcji w spoleczeństwie. W pewnym sensie można mówić o emigracji Kościola ze spoleczeństwa.

W efekcie zmianom ulega świadomość spoleczna. Jest ona dodatkowo modyfikowana ogólniejszymi tendencjami. Jedną z nich jest pogląd o konieczności zbudowania ogólnoeuropejskiego systemu wartości egzystujacego poza istniejacymi różnicami kulturowymi, etnicznymi i historycznymi. Zwolennicy tego poglądu opowiadają się za integracją ponad wszelkie podzialy i różnice. Zwolennicy drugiego poglądu dążą do budowania tożsamości grupowej (narodowej) uwzględniającej specyfikę systemu wartości wlasnej grupy. Reprezentanci tego pogladu moga być nazwani autonomistami. W znacznej mierze reprezentanci tej drugiej tendencji dążą do realizacji wyznaczonych sobie celów w oparciu o wartości religijne oraz z wykorzystaniem instytucjonalnego Kościoła.

Analiza przemian systemu wartości wspólczesnego spoleczeństwa polskiego winna uwzględniać w znacznym zakresie problematykę wplywu religii na tempo, charakter i treść przemian w systemie wartości społeczeństwa.

Stawiając problem roli religii w przemianach systemu wartości wspólczesnego spoleczeństwa polskiego, istotne są dwa wzajemnie się uzupelniające elementy: po pierwsze, jest to problem relacji zachodzących pomiędzy zinstytucjonalizowanym Kościolem a spoleczeństwem, po drugie, istotne jest pytanie, w jaki sposób otoczenie zewnętrzne wymusza zmiany w Kościele. Pojawia się tu problem, na ile jest możliwa realizacja w praktyce idei aggiornamento, propagujacej dążenie dostosowania do wymogów współczesności zasad funkcjonowania Kościola. Obok tych dwóch zagadnień ważny jest również problem, który można

${ }^{1}$ J. Mari ański: Żyć parafia. Socjologiczne aspekty kierowania wspólnota parafialna. Wroclaw 1984 s. 22.

${ }^{2}$ Por. J. Ma r i ań s k i: Wiedza o parafii i Kościele jako element więzi parafialnej. „Ateneum Kapłańskie". R. 1974 z. 2 s. nn.

${ }^{3} \mathrm{~K}$. M a n n h i m: Czlowiek i spoleczeństwo w dobie przebudowy. Warszawa 1974 s. 73. 
sformulować w postaci pytania: czy możliwe jest skonstruowanie paradygmatu badawczego, opisującego charakter tych przemian?

Treść i tempo zmian uzależnione jest, z jednej strony od aktualnych warunków, z drugiej strony, przeszlość ciąży na aktualnych zachowaniach, wytyczając granice możliwe do ich zaakceptowania. Tworzeniu się nowych relacji i struktur świadomościowych towarzyszy pojawianie się synkretycznych wartości oraz konfliktów $\mathrm{w}$ ich doborze przez jednostkę. Poszczególne segmenty struktury spolecznej w różny sposób $\mathrm{i} w$ różnym tempie przyswajają zmiany, a ich wewnętrzna treść jest atrakcyjna na dość zróżnicowanym poziomie.

Ewolucja świadomości społecznej powoduje zmianę postrzegania roli Kościoła w spoleczeństwie. Autorzy aktualnych sondaży opinii na temat roli Kościoła we wspólczesnym społeczeństwie wskazują na obniżanie się jego znaczenia. Formuluja przy tym wnioski o upadku jego spolecznego autorytetu i kryzysie.

Analiza istniejącego status quo prowadzi do różnych konkluzji ich autorów. Przy czym są to dość często alarmujące prognozy, wskazujące, że znaleźliśmy się w sytuacji przelomu, po którym załamią się dotychczasowe podstawy i schematy funkcjonowania różnych grup. Odkrywanie nowego świata poprzez krytykę świata zastanego nie daje odpowiedzi na pytanie, jak ów nowy świat będzie (powinien być) zorganizowany ${ }^{4}$.

Te alarmujące wizje są potęgowane analizą spadku znaczenia i społecznej akceptacji wybranych instytucji, będących podstawą dotychczasowego ladu spolecznego. Podstawą jest tu na przykład analiza roli Kościoła we współczesnym spoleczeństwie, czy rodziny jako podstawowego nośnika przekazu wartości dla najmłodszego pokolenia. Zauważalne tu zmiany sa podstawa do tworzenia tego typu sadów. Zauważył to w jednej ze swoich prac ks. Janusz Mariański pisząc: Istnieje w naszym kraju tendencja - także śród socjologów - do przedstawiania spoleczenstwa w jak najbardziej czarnych i ponurych barwach. Socjologowie nie maja jednak zamiaru podważania moralności czy dyscypliny spolecznej, chociaż czasem wydaja się "niecierpliwi $w$ oczekiwaniu na negatywne przemiany moralności. Społeczeństwo jest w ustawicznym kryzysie, jest »chore « - twierdzi się. Im bardziej negatywne opinie wypowiada się o polskim spoleczeństwie, tym ma się większa szansę na pozyskanie postuchu w pewnych kręgach decyzyjnych $i$ opiniotwórczych. Powszechna jest także świadomość, że żyjemy w fazie przej-

${ }^{4}$ E. Mokrzy c ki: Dwa style myślenia o przyszlości. W: O spoleczeństwie i teorii spolecznej. Księga poświęcona pamięci Stanislawa Ossowskiego. Warszawa 1985 s. 180. 
ściowej i nie bardzo wiadomo, jak dlugo potrwa nasza wędrówka do normalności i co ona w istocie oznacza ${ }^{5}$.

Wydaje się, że bardziej jest tu uprawomocniona postawa chlodnego opisu niż wartościowania. Tym bardziej, że część tych zjawisk nie poddaje się prostemu opisowi. Jak zauważyl P. Sztompka ${ }^{6}$ proces pokomunistycznej transformacji ma charakter złożony, wielowątkowy. O jego ostatecznym ksztalcie decydują zarówno czynniki ładu instytucjonalnego, jak i o wiele mniej uchwytne empirycznie o charakterze mentalno-kulturowym. Stąd należy podejmować badania ujmujace proces transformacji $\mathrm{w}$ sposób integralny, uwzględniający zarówno wymiar instytucjonalny, organizacyjno-prawny, polityczny i ekonomiczny oraz zmiany związane $\mathrm{z}$ kultura, moralnymi skutkami transformacji, zmianami w subiektywnych orientacjach życiowych jednostek.

Tym bardziej, że z częścią tych procesów mamy do czynienia po raz pierwszy. Są one dla teoretyków i praktyków opisujących życie spoleczne zjawiskami dotąd nieznanymi, bądź nie występującymi w takim natężeniu. Szybkie prognozowanie jest tu dzialaniem, które może się nie sprawdzić. Łatwo o pomylkę. O możliwości tworzenia szerszych teorii do nowych sytuacji spolecznych pisal przed laty Stanisław Ossowski: W okresie gwaltownych zmian teoretyk nie podqża za życiem. Zmiany rzeczywistości sq wtedy szybsze niz myśl refleksyjna, którq tempo przemian przyprawiać może o zadyszkę, gdy tymczasem potrzeba jej dlugiego oddechu? ${ }^{7}$.

Takie podejście wymaga żmudnych wielowymiarowych badań. Stąd latwiej stawiać blyskotliwe diagnozy, mało poparte rzetelnie udokumentowanymi badaniami. Za to nośne w wymiarze publicystycznym, dające ich autorom medialna popularność. Dlatego diagnoza spoleczeństwa końca wieku doczekala się wielu opisów. Możemy spotkać w literaturze, że transformacja końca ubieglego wieku wytworzyla w Polsce spoleczeństwo postautorytarne, spoleczeństwo posttotalitarne, społeczeństwo realnej demokracji, społeczeństwo postsolidarnościowe, spoleczeństwo wielkiej transformacji, społeczeństwo postkatolickie, spoleczeństwo postteologiczne. Nazw tych można mnożyć jeszcze więcej.

Charakterystyczne jest dla autorów próbujacych opisywać współczesne spoleczeństwo, będace faktycznie pod wplywem przyśpieszonych zmian dążenie do uogólnienia. Badając jedna, wybraną sferę rzeczywistości społecznej próbuja

${ }^{5}$ J. Mari ań ski: Kryzys moralny czy transformacja wartości? Studium socjologiczne. Lublin 2001 s. 422.

${ }^{6} \mathrm{P} . \mathrm{S}$ z $\mathrm{t}$ o m pka: Kulturowe imponderabilia szybkich zmian spolecznych: zaufanie, lojalność, solidarność. W: Imponderabilia wielkiej zmiany. Mentalność, wartości spoleczne czasów transformacji. Red. P. S z to m p k a. Warszawa-Kraków 1999 s. 266 i nast.

S. O s s o w s ki: Z zagadnień struktury spolecznej. Warszawa 1968 s. 87. 
tworzyć ogólne wizje opisujące społeczeństwo jako calość. Metodologicznie nie jest to poprawne przedsięwzięcie, natomiast dość często nadaje rozglos jego twórcy. Watpliwości może również budzić sposób gromadzenia danych, na których oparte są uogólnienia. Dość często jest tak, że są one wykonywane na zamówienie konkretnej instytucji, której zależy na wynikach potwierdzających przyjęte wcześniej przez nią hipotezy.

Niewątpliwie mlodzież jest bardziej otwarta na nowe tendencje, pokolenie starszych z kolei charakteryzuje się większym konformizmem w stosunku do zastanych wartości. Chcialoby by mogly one trwać międzypokoleniowo. Jest tu oczywista sprzeczność. Wszak to sami rodzice nauczyli dzieci samodzielności, a gdy te ja osiagnęly zaczęła ona im przeszkadzać. Zauważyła to M. Mead piszac, że rodzice i nauczyciele przestali uważać dzieciństwo i wiek mlodzieńczy za zjawiska same przez się zrozumiale. Próbowali raczej dopasowywać wychowanie do potrzeb dziecka niz naginać dziecko do sztywnych regut wychowawczych ${ }^{8}$. Tworzyly się, więc zręby do powstania kultury prefiguratywnej, w której starsze pokolenie uczy się również od mlodszego. Przez co wzrasta autorytet mlodszego pokolenia i spadek autorytetu generacji rodziców. Młode pokolenie będąc dla siebie autorytetem $\mathrm{w}$ swobodny sposób dobiera korzystne i funkcjonalne dla siebie wartości. Ma to również implikacje w wyborze wartości religijnych.

Tendencje te zauważył w jednych z pierwszych badań poświęconych religijności wiejskiej ks. prof. Janusz Mariański w rejonie płockim. Na podstawie zrealizowanych badań wyróżnił on cztery typy katolików: katolicy o pelnej kościelnej religijności, katolicy o niepelnej religijności kościelnej, katolicy o religijności selektywnej oraz katolicy obojętni religijnie. Poszukując zmiennych, które mają wplyw na prezentowane postawy wobec religii zauważyl, że istnieje silna zależność statystyczna pomiędzy strukturq badanych a typami ich postaw wobec religii. Pokolenie młodsze w wieku 16-24 lat przejawia najniższe wskaźniki kościelnie zorientowanej religijności i najwyższe wskaźniki religijności selektywnej $i$ indyferentyzmu religijnego. W miare jak przechodzimy od mlodszych do starszych pokolen, narasta zasięg postaw świadczacych o kościelnie uksztaltowanej religijności i zmniejsza się zasięg postaw »nonkonformistycznych «wobec religii”.

Cytowany fragment pracy będącej efektem badań zrealizowanych na przestrzeni prawie dziesięciu lat pokazuje, że podstawowym celem Autora byl opis tworzących się nowych związków z parafią w tradycyjnej, wiejskiej spoleczności i emigrantów do rejonu uprzemyslowionego. Szerszy kontekst teoretyczny tych procesów Autora zbyt mocno nie interesuje. Walor tych badań z perspektywy

\footnotetext{
${ }^{8}$ M. M e a d: Trzy studia. T.1-2. PIW. Warszawa 1986 s. 19.

${ }^{9} \mathrm{~J}$. M a r i án s k i: Dynamika przemian religijności wiejskiej w rejonie plockim $w$ warunkach industrializacji (1967-1976). Poznań-Warszawa 1984 s. 429.
} 
czasu jest o tyle ważny, że zostal zarejestrowany stan świadomości konkretnego środowiska w momencie jej intensywnego przekształcania się.

Drugim bezsprzecznym walorem zrealizowanych badań jest to, że ich Autor realizowal badania niejako w sprzeczności do obowiazujących wówczas tendencji, starających się udowodnić skuteczność procesu laicyzacji i upowszechniania się socjalistycznych wzorców osobowych. Badania te a priori zakładały, że oficjalna doktryna państwa socjalistycznego ma realne odzwierciedlenie w dominujących w spoleczeństwie uznawanych i realizowanych wartościach. Inne podejście do problemu w analizowanych badaniach spowodowalo, że mamy współcześnie możliwość odniesienia się do sytuacji sprzed okolo czterdziestu lat poprzez pryzmat realnie zachodzacych w ówczesnym spoleczeństwie procesów, a nie wedlug uznawanych oficjalnie poglądów.

Ta ważna z punktu widzenia współczesności praca ma swój największy walor ze względu na rejestrację zachodzących wówczas procesów, jest niejako fotografią ówczesnej świadomości. Szerszy kontekst teoretyczny jest mniej istotny. Autora interesuje bardziej to, jakie zmienne demograficzne maja wplyw na nowopowstające zjawiska. Tworzenie bardziej rozwiniętego modelu nie interesuje Autora. Na tym etapie wiedzy interesujace było zweryfikowanie przyjętych przez Autora hipotez. W konkluzji pracy autor pisze: Zebrany i przeanalizowany materiat pozwolit zweryfikować wiodqca hipotezę niniejszej pracy, wedlug której w warunkach postępujacego zaawansowania industrializacji w rejonie wiejskim nie dochodzi do zaniku postaw religijnych w kierunku postaw ateistycznych, lecz do ksztaltowania się postaw wybiorczych wobec religii, charakteryzujacych się częściowq identyfikacjq $z$ wiarq $i$ życiem wspólnoty kościelnej. Stwierdzony kierunkowy trend rozwojowy religijności wiejskiej wskazuje, że w srodowiskach wiejskich objętych intensywnej industrializacji bardziej upowszechnia się religijność selektywna niz indyferentyzm religijny i ateizm ${ }^{10}$.

Kolejne badania są kontynuacją zainteresowań Autora problematyką świadomości mlodzieży. Lektura prac ks. prof. Janusza Mariańskiego pokazuje, że dąży w swoim warsztacie by stawiane uogólnienia i teoretyczne konstrukcje byly poparte rzetelnymi badaniami empirycznymi. Swoistością warsztatu Autora jest to, że nie stawia jednoznacznych twierdzeń, pozostając sobie i czytelnikowi znaki zapytania. Wszak już tytuly prac sugerują że ks. Profesor raczej wskazuje na to, że faktycznie jesteśmy spoleczeństwem w fazie „stawania się", mniej stała konstytucją o ugruntowanym systemie wartości.

Najistotniejsze w pracach Autora staje się pokazanie opozycji, w jakich funkcjonuje analizowany problem. To do czego dążą inni socjologowie to ustale-

${ }^{10}$ Tamże, s. 451. 
nie statycznego wzorca, do którego można przyporzadkować najlepiej cale spoleczeństwo (np. wizja spoleczeństwa sukcesu, społeczeństwa aspirującego, spoleczeństwa refleksyjnego itp.). Takie przyporządkowanie staje się zazwyczaj artefaktem. Wszak na ile jest uprawomocnione stwierdzenie, że jesteśmy spoleczeństwem aspirujacym, gdy rozszerza się zakres spolecznego ubóstwa, a marzenia Polaków sa coraz bardziej prozaiczne, związane z zaspokojeniem codziennych potrzeb. Społeczeństwo aspirujące może odnosić się co najwyżej do pewnej, waskiej grupy ludzi

Ks. prof. J. Mariański idzie w nieco innym kierunku, co wynika z jego podejścia do analizy interesujacych go procesów spolecznych. Widzi to, że są one in statu nascendi. Koniec ich jest często nieprzewidywalny, bo zmiany nie sa jednorodne. W różnych grupach zachodzą w różnym tempie i w różnym kierunku. Zauważyl to Autor w zrealizowanych pod koniec lat 80 . badaniach na temat wartości religijnych i moralnych mlodzieży ${ }^{11}$. Konkluzja badań byla następująca: Badania pozwolity na uchwycenie zmian w świadomości mlodzieży dotyczacych stosunku do wiary oraz uznawanych wartości moralnych. Moment badan byl istotny, wszak tworzyly się na przelomie lat 80. i 90. podstawy spoleczeństwa pluralistycznego i obywatelskiego, dajqce możliwość zmiany w postawach ludzi wykorzystujac wolność i podmiotowość jednostki. Zrealizowane badania pozwolity Autorowi potwierdzić hipotezę zakladajqca ujednolicanie się cech uznawanych wartości mlodzieży. Autor napisal: Wyniki badań nad wartościami mlodziezy polskiej potwierdzajq teze o postępujacym ujednolicaniu się uznawanych wartości $w$ przekroju podstawowych cech demograficznych i spolecznych mlodego pokolenia Polaków. Różnice między młodzieżq męska żeńskq, uczaca się w szkolach ponadpodstawowych i na uczelniach, mieszkajacq na wsi i w mieście, nie sq na ogól znaczqce. Bardziej różnicuje aksjologicznie poglądy badanej mlodzieży religijność w jej różnych wymiarach. Stosunkowo zbliżone wybory poszczególnych wartości, jak $i$ ich hierarchia, $w$ poszczególnych kategoriach demograficzno-spolecznych świadczq o tym, że istniejace $w$ naszym kraju mechanizmy przekazywania wartości i norm bardziej sprzyjajq ujednoliceniu postaw mlodzieży, niż ich różnicowaniu ${ }^{12}$.

Z tej ogólnej konstatacji Autor wyprowadza bardziej szczegółowe wnioski. Zgodnie z przyjętą przez siebie metodą daje ramy, w których mieści się badane zjawisko, tj. postawy moralne mlodych Polaków. Odpowiedzi szuka formulując pytanie: czy wiodaca tendencja w postawach Polaków jest rygoryzm lub relatywizm? Stawiając ten problem w taki sposób, jednocześnie uściśla tę kwestię pisząc, jakie relacje pomiędzy tymi stanowiskami go interesują i jak można je zde-

\footnotetext{
${ }^{11}$ Por. J. Mari a ń sk i, W. Z d an i e w i c z: Wartości religijne i moralne mlodych Polaków (raport z badan ogólnopolskich). Warszawa 1991.

${ }^{12}$ Tamże, s. 215
} 
finiować. Badania socjologiczne nad rygoryzmem i relatywizmem moralnym wiqża się z pytaniem: które z nakazów moralnych, cech charakteru i wzorów zachowan powinny obowiazywać powszechnie $i$ we wszystkich okolicznościach, które zaś maja wartość względnq i zależq od okoliczności. Bardzo silna pochwala nie dopuszczajqca wyjątków lub bardzo silna nagana, również nie dopuszczajaca wyjatków, odzwierciedlajq rygoryzm moralny. Częściowa aprobata i zarazem częściowa dezaprobata wskazuja na relatywizm moralny, a przynajmniej daleko posunięta tolerancję wobec ocenianych wartości i norm (uzależnienie oceny od różnych okoliczności) ${ }^{13}$. Które $\mathrm{z}$ tych stanowisk dominuje w świadomości młodzieży w świetle zrealizowanych badań. Wszystkie normy o charakterze uniwersalnym i kategorycznym - pisze Autor - ograniczajace indywidualnq wolność jednostki, sq przez częśś ludzi wspólczesnych kwestionowane i liberalizowane. Upowszechniajaca się akceptacja prawa jednostki do samookreślenia się jednostki $w$ dziedzinie moralnej niesie ze sobq daleko idqce konsekwencje dla życia religijnego. Wiele wskazuje na to, że część katolików znajduje się w sytuacji dysonansowo-stresowej. Nie ma zgodności między osobiście uznawanym systemem wartości a systemem wartości wynikajacym z wiary propagowanej przez Kościól. Część katolików żyje wedlug norm i regut, które nie maja usprawiedliwienia (legitymizacji) w Kościele. Rozbieżność między systemem wartości upowszechniajacym się $w$ spoleczeństwie a systemem wartości zwiq̨anym $z$ wiarq jest znaczna ${ }^{14}$.

Dostrzeżone ogólne tendencje w spoleczeństwie końca lat 80. w pelni dotyczą również młodzieży. W konkluzjach omawianych badań Autor napisał: Proces odchodzenia od rygoryzmu moralnego $w$ stronę relatywizmu jest »in statu fieri« w calej badanej zbiorowości mlodzieży. Zarysowaly się pewne odmienności tego procesu ze względu na cechy spoleczno-demograficzne badanych osób. Uczniowie częściej niż studenci wskazuja na zasady etyczne jako punkty odniesienia w ich decyzjach moralnych, częściej nie znajduja usprawiedliwienia dla czynów moralnie nagannych, rzadziej wypowiadaja opinie zrelatywizowane o różnych cechach charakteru i postawach ludzkich. W tym wlaśnie znaczeniu kobiety przejawiaja bardziej rygorystyczna moralność niż mężczyźni, młodzież wiejska bardziej niż mlodzież miejska ${ }^{15}$. Pokazywane przez Autora zależności ze zmiennymi demograficznymi dowodzą, że wartości moralne maja silne spoleczne korzenie $^{16}$. Sa uwarunkowane kontekstem, w jakim odbywa się proces wychowania oraz cechami otaczającego środowiska. Przy czym nie są one w pelni ukonstytuowane oraz nie jest jasny kierunek ich zmian. Z perspektywy zrealizo-

${ }^{13}$ J. Ma ri ań sk i: Relatywizm moralny $w$ okresie przemian spolecznych w Polsce. W: Religia $w$ dobie przelomu w Polsce. Red. L. A d a m c z u k. Warszawa 1992 s. 52.

${ }^{14}$ Tamże, s. 64-65.

${ }^{15}$ Tamże, s. 65.

${ }^{16}$ Por. J. M a ri a ń s ki: Wprowadzenie do socjologii moralności. Lublin 1989 s. 234. 
wanych z końcem lat 80 . i poczatków lat 90 . badań Autor próbuje prognozować konsekwencje odnotowanych zjawisk. Jest dość ostrożny we wnioskach ze względu na to, że istnieją ograniczone przesłanki do precyzyjniejszej prognozy a analizowany problem dość szybko się zmienia. Autor napisal: Na tle poczynionych ustalen warto podjać dalsze próby charakterystyki wartości religijnych $i$ moralnych uznawanych przez młodzież polskq lat dziewięćdziesiatych. Jeżeli nawet akceptowane przez mlode pokolenie wartości i dominujące cechy stylu życia nie zmieniaja się dramatycznie, to z pewnościa przedstawione dane z końca lat osiemdziesiatych nie będq już calkowicie adekwatne do sytuacji ostatniej dekady $X X$ wieku ${ }^{17}$. Z perspektywy końca lat 90 . zjawiska te konkludowal w następujący sposób: Proces selektywności w religijności polskiej trwa od wielu lat, nasilal się $w$ latach sześćdziesiatych i siedemdziesiqtych, zostal nieco przyhamowany w latach osiemdziesiatych $i$ znowu zyskat na sile od $1989 \mathrm{r}$. Zaznacza się on mniej lub bardziej wyraźnie u około dwóch trzecich polskich katolików. Selektywność (wybiórczość) w religijności kościelnej dotyczy kwestionowania lub negowania dogmatów wiary, kwestionowania lub negowania wartości i norm moralnych, zaniedbywania lub pelnej absencji w praktykach religijnych, rozluźnienia bądź zaniku więzi z instytucjami religtjnymi. Często wiara i niewiara, pewność i zwatpienie, aprobata i odrzucenie, mieszaja się ze soba ${ }^{18}$.

Wartości religijne w przeszłości mialy doniosłe znaczenie w kreowaniu przez jednostkę indywidualnego sensu życia. W kościele ludowym w zasadzie byly one jedynym wyznacznikiem uzasadniajacym sens ludzkiej egzystencji. Wspólcześnie religia stanowi tu jedną z alternatyw. Takie konkluzje potwierdzaja również badania Autora na temat sensu życia mlodzieży ${ }^{19}$, zrealizowane na przelomie lat 80. i 90. Autor dostrzeg1, że istnieje korelacja pomiędzy postawami prezentowanymi przez mlodzież szkolną w stosunku do religii a ich uzasadnianiem wlasnego sensu życia. Ważnq role $w$ usensowieniu życia-chociaż nie $w y$ lqcznq-odgrywajq wartości religijne ${ }^{20}$. Otrzymane wyniki pozwolily stwierdzić, że wartości religijne funkcjonują w świadomości mlodzieży na równi $z$ innymi wartościami. Jak pisze Autor, rozszerza się wachlarz wartości, które mogą uzasadniać sens życia badanej młodzieży.

Potwierdzają to również późniejsze badania (zrealizowane w szkolach średnich w latach 1994-1996). Nieco ponad co dziesiaty badany wybral wariant odpowiedzi, wskazujacy wylq̨cznie na religię jako źródlo sensu życia $(10,4 \%)$. Ci

${ }^{17}{ }^{17}$ J. Mariański, W. Zd dani e wi c z, dz. cyt., s. 215.

${ }^{18} \mathrm{~J}$. Mari a ń s k i: Kościól katolicki w spoleczeństwie obywatelskim. Refleksje socjologiczne. Lublin 1998 s. 120.

${ }^{19}$ Por. J. Mari án ski: W poszukiwaniu sensu życia. Szkice socjologiczno-pastoralne. Lublin 1990.

${ }^{20}$ Tamże, s. 250 
badani poszukujq odpowiedzi na nurtujq̨e ich pytania wlaśnie w religii, w niej odnajdujq uzasadnienie dla wartości, bez których nie można żyćc ${ }^{21}$. Występujące alternatywne sposoby uzasadniania wlasnego sensu życia przez młodzież szkól moga stanowić zagrożenie dla wiary. Otrzymane wyniki dotyczące religijnego uzasadnienia sensu życia przez mlodzież konkluduje następujaco: Niezbyt wysokie wskaźniki aprobaty religijnego sensu życia i wysokie wskaźniki aprobaty niereligijnych wymiarów sensu życia dowodza, że religia powoli traci znaczenie jako jedynie usensowniajaca ludzkie życie. Cechy spoleczno-demograficzne odgrywaja rolę tylko częściowo różnicujaca postawy mlodzieży wobec religijnego sensu życia, bardziej znaczqce sq cechy religijne. Jeżeli nawet religia stanowi dla mlodzieży ważnq instancje, do której można się odwolać, to wcale nie znaczy to, by dostarczala ona zawsze cel i sensu na co dzień, by należala do obiektywnych warunków $i$ wyznaczników codziennego życia ${ }^{22}$.

Zrealizowane badania, porównanie trendów występujacych w polskim spoleczeństwie jako całości oraz analiza tych problemów w innych wspólczesnych spoleczeństwach sklaniać powinny do dość pesymistycznych prognoz. Autor jednak formuluje wnioski idące $w$ innym kierunku. W charakterystyczny dla siebie sposób próbuje szukać przestrzeni, w jakiej funkcjonują badane zjawiska. Ta przestrzeń tym razem jest określona w postaci opozycji postaw: pomiędzy nadzieja a zwatpieniem. Wszak zwątpienie mogą budzić analizy surowych wyników. Natomiast bardziej doglębna analiza pokazuje, że deklarowane poczucie bezsensowności, oznaczajqce deficyt sensu, obejmuje bardzo cienkq warstwe społecznq, zamykajacq się $w$ granicach kilku procent (najwyżej 10\%). Sq to prawdopodobnie jednostki, dla których wszelkie systemy sq puste i nic z nich nie wynika dla życia, lub ci, którzy nie potrafili się odnaleźć, chociaż tęsknia za pelnym i dojrzalym życiem ludzkim ${ }^{23}$.

Gdzie jest więc nadzieja? Autor stwierdza: Postawy mlodzieży szkolnej wobec sensu życia balansuja jakby między kontrolowanq nadzieja $i$ żywiolowym zwatpieniem, rzadko wychylaja się w stronę wyraźnego bezsensu. Postawy wobec religii sq cechq wyrażnie różnicujacq postawy mlodzieży szkolnej wobec sensu życia. Osoby o intensywnych postawach religijnych (glęboko wierzqcy) charakteryzujq się wyraźnie wyższym poczuciem sensu życia, częśsiej także doświadczaja $w$ życiu zadowolenia $i$ sensu, rzadziej ulegaja frustracji egzystencjalnej ${ }^{24}$. Nadzieją jest to, że młodzież cechuje wysoki poziom ogólnego zadowolenia z życia. Często rozmyśla o swojej przyszłości, nie wykazując symptomów zachwianego

21 J. Mariań ski: Między nadzieja i zwatpieniem. Sens życia w świadomości mlodzieży szkolnej. Lublin 1998 s. 270.

${ }^{22}$ Tamże, s. 287.

${ }^{23}$ Tamże, s. 356

${ }^{24}$ Tamże, s. $359-360$. 
poczucia sensu życia. Deklarowane poczucie zadowolenia z życia jest dogodnym stanem psychicznym dla ksztaltowania się dojrzałej ich osobowości.

Zrealizowane w latach 2002-2003 badania dotyczące wartości prorodzinnych w świadomości mlodzieży szkól średnich ${ }^{25}$ dość ściśle są powiązane z problematyką roli religii $\mathrm{w}$ kreowaniu tych wartości. Badania sa zrealizowane $\mathrm{w}$ podobnym paradygmacie metodologicznym i postawie badawczej jak poprzednio analizowane wyniki. Znów stara się dostrzec fakt, że opisywane zjawisko znajduje w procesie intensywnych zmian. Stąd dla Autora istotne jest wskazanie granic, w jakich występuje ten problem.

Praca jest oparta na bogatej bazie źródlowej. W charakterystyczny dla siebie sposób Autor traktuje problem funkcjonowania wartości prorodzinnych w wymiarze dynamicznym. Pokazując jak w kontekście dostępnej literatury analizowane są te zagadnienia. Interesuje go przede wszystkim to, w jaki sposób procesy sekularyzacji wplywają na zmianę postaw mlodzieży w stosunku do rodziny $\mathrm{i}$ wartości z nią związanych.

Część empiryczna pracy to weryfikacja siedmiu hipotez badawczych. Jest przy tym interesujące, że analizuje się zarówno rodzinę jako wartość autoteliczna, jak również widzi te aspekty życia czlowieka, które realizują się w obrębie rodziny. Swoje konkluzje Autor opiera na rozleglych badaniach przeprowadzonych na terenie calej Polski. W badaniach uczestniczylo lącznie 2256 respondentów, uczniów szkól średnich. Przy takiej liczebności próby można mieć pewność, że uzyskane wyniki są obiektywne.

Dane statystyczne uzyskane w badaniach pokazuja, że $w$ calej zbiorowości mlodzieży szkót średnich wskaźnik glęboko wierzqcych wahat się od 11,4\% do $18 \%$, wierzacych - od $52,4 \%$ do $66,4 \% \%^{26}$. Takie sa dane. Jednak jak zauważa Autor ogólna identyfikacja religijna nie musi potwierdzać się calkowicie w bardziej szczególowych kwestiach dotyczqcych wiary religijnej. W miarę przechodzenia od bardziej ogólnych do bardziej konkretnych treści doktryny religijnej zmniejszaja się wskażniki aprobaty, wzrastaja zaś wskaźniki zwatpienia i dezaprobaty $^{27}$.

Uzyskane dane potwierdzają powszechną wśród socjologów tezę o znacznej stabilności w deklarowanych postawach odnoszących się do ogólnej przynależności wyznaniowej i religijnej. Bóg zaś pozostaje w dalszym ciagu centralnym obiektem postaw mlodzieży. Zmienia się natomiast jego wizja i nie zawsze jest

${ }^{25}$ Por. J. Mariań ski: Między sekularyzacją $i$ ewangelizacją. Wartości prorodzinne w świadomości mlodzieży szkól średnich. Lublin 2003.

${ }^{26}$ Tamże, s. 177.

${ }^{27}$ Tamże, s. 179 
on rozumiany w sensie chrześcijańskim, jako Bóg osobowy. Jednak jak zauważa Autor wśród młodzieży zaczynają się kształtować i konsolidować nowe środowiska ateistów, agnostyków i przeciwników Kościola oraz nowe ruchy religijne ${ }^{28}$. Dostrzegając te nowe zjawiska Autor próbuje kreślić kolejną opozycję analizowanych problemów. Jego zdaniem, przemiany świadomości mlodego pokolenia idq $w$ kilku rozbieznych kierunkach. Silne sq tendencje sekularyzacyjne zwiqzane $z$ indywidualizacjq moralnq, ale także przeciwstawne im tendencje reewangelizacyjne. Wiele faktów wskazuje na to, ze w przemianach wartości prorodzinnych mieszaja się pozytywne i negatywne aspekty, a niekiedy zaznaczaja się nawet sprzeczne tendencje. Efektem tych oddzialywan jest fakt, że niejednokrotnie w swiadomości zbiorowej mlodych Polaków wspólistnieja »stare i nowe wartości«. Nie grozi nam - przynajmniej w najbliższej przyszłości - jakaś katastrofa w świecie wartości. Można raczej mówić o swoistej ambiwalencji przemian wartości prorodzinnych, o szansach i ryzyku, o stratach i zyskach, o poszerzajqcej się sferze przyzwolenia spolecznego na postawy i zachowania dezaprobowane w modelu moralności gloszonej w Polsce przez Kościól katolicki ${ }^{29}$.

Jaki obraz polskiego spoleczeństwa, jaki wizerunek mlodego Polaka można stworzyć z perspektywy badawczej proponowanej przez ks. Prof. Janusza Mariańskiego? $\mathrm{Na}$ poziomie wiary i praktyk religijnych nie mamy do czynienia $\mathrm{w}$ ostatnich latach $\mathrm{z}$ większymi zmianami. $Z$ uzyskanych danych empirycznych można wnosić, że w latach dziewięćdziesiątych $w$ zakresie globalnych postaw wobec religii nie dokonaly się jakieś radykalne zmiany. Zarówno wskaźniki autodeklaracji wiary, jak i praktyk religijnych utrzymuja się na względnie statym poziomie, z jedna jednak niewielkq modyfikacja. Dotyczy ona zmniejszania się zasięgu osób deklarujących się jako glęboko wierzqcy (obecnie okolo 10\%), co wskazywaloby na nieznaczna zmianę nasilenia się pozytywnego stosunku do reli$g i i^{30}$.

Zmiany religijności wspólczesnego spoleczeństwa są konsekwencją ogólnych przemian w nim zachodzacych. Zauważyl to Autor w jednej ze swoich wcześniejszych książek dotyczących systemu wartości wspólczesnego spoleczeństwa polskiego. We Wstępie tego studium socjologicznego ${ }^{31}$ Autor pisze: Spoleczensstwo polskie jest $w$ fazie przemian spolecznych, które nie przebiegaja jednoznacznie. Z jednej strony zaznaczaja sie jeszcze silne procesy instytucjonalizacji $i$ tradycji, powodujqce umocnienie się struktury spolecznej, dzialajqce

${ }^{28}$ Por. tamże, s. 181

${ }^{29}$ Tamże, s. 485.

${ }^{30} \mathrm{~J}$. Mariań ski: Katolicyzm polski w perspektywie europejskiej: misja czy przystosowanie, czyli z jakq religijnościq do Europy? W: Socjologia religii. T 2. Katolicyzm polski w warunkach Unii Europejskiej: szanse, zagrożenia, obawy i nadzieje, dz. cyt., s. 69-70.

${ }^{31}$ Por. J. Ma ri a n s k i: Kryzys moralny czy transformacja wartości? Studium socjologiczne. Lublin 2001 s. 10. 
hamujqco na zmiane spolecznq, przystosowujqce mlode pokolenie do istniejacych wartości, norm $i$ wzorów zachowań. Podtrzymuja one, a nawet wzmacniaja, zastanq strukturę wartości i interesów. Z drugiej strony nasilaja się procesy indywidualizacji, niosqce ze sobq cyrkulacje przelotnych ról i statusów, niebezpieczeństwo głębokiego rozpadu wartości, norm i więzi między ludźmi (anomia), ale i szanse wolnego, samodzielnego oraz odpowiedzialnego ksztaltowania wlasnego projektu życia. Przejściowy okres, w którym żyjemy, jest postrzegany i analizowany zarówno w kategoriach kontynuacji, jak i dyskontynuacji ${ }^{32}$.

Cytowany fragment pokazuje, że na poziomie spoleczeństwa rozumianego jako ogól Polaków Autor dostrzega złożoność procesów, prowadzącą do niemożliwości ustalenia uniwersalnego, jedynego wzorca mogącego shużyć nie tylko jednoznacznemu opisowi, ale dającemu podstawę do tego by stworzyć w miarę statyczną konstrukcję teoretyczną. Zazwyczaj interesuje go konkretne zjawisko w procesie tworzenia się. Np. kreśląc wizję polskiego katolicyzmu w kontekście integracji z Unia Europejska stawia problem: czy dokonujace się procesy spowoduja, że mocna dotąd polska religijność może spelnić szczególną misję w nowej wspólnocie, czy też będą raczej dominować procesy przystosowawcze ${ }^{33}$. Opowiada się raczej za tą drugą tendencją.

Na podstawie prowadzonych przez siebie badań chlodno odnosi się do tez o rychlej sekularyzacji i marginalizacji Kościoła w spoleczeństwie polskim, tezy tak często powtarzanej przez część socjologów, podkreślających zanik praktyk religijnych i więzi wierzacych z parafią. Znów stara się dostrzegać ten problem w nieco szerszym, historycznym kontekście, uwzględniającym polską specyfikę. Dostrzega, co prawda, że kryzys moralny i religijny, rozumiany jako proces deinstytucjonalizacji, przejawia się najdobitniej w wybiórczym traktowaniu moralnej oferty Kościola, aż po jej calkowite odrzucenia. Deinstytucjonalizacja oznacza, że wiara i moralność nie sq $w$ takiej mierze jak dawniej zinstytucjonalizowane $i$ spolecznie sankcjonowane, niektóre ich elementy podlegaja glębokiej transformacji $i^{34}$.

W książce o roli Kościoła katolickiego w społeczeństwie obywatelskim ${ }^{35}$ podkreśla, że procesy sekularyzacji nie zachodzą w naszym kraju tak mocno ze względu na dotychczasowy sposób funkcjonowania Kościola w spoleczeństwie. Pisze on o dalszym utrzymywaniu się Kościola ludowego w spoleczeństwie (przypomnienie hipotezy ks. prof. Wl. Piwowarskiego). Zauważa natomiast, że w warunkach transformacji Kościół poszukuje nowej tożsamości społecznej, wyka-

\footnotetext{
${ }^{32}$ Tamże, s. $10-11$.

${ }^{33}$ Por. J. Ma ri a ń s ki: Katolicyzm..., dz. cyt., s. 82.

${ }^{34}$ J. Ma r i á s k i: Między sekularyzacja..., dz. cyt., s. 494

${ }^{35}$ Por. J. Mari ań s ki: Kościól..., dz. cyt., s. 117.
} 
zując wiele oznak i symptomów przemiany oraz zrozumienia „znaków czasu”36. Oczywistym jest dla Autora, że odchodzi się od zuniformizowanej wspólnoty do strukturalnej indywidualizacji. Ale nie jest to proces zaniku wartości religijnych.

Odnosząc swoje analizy do przemian świadomości młodzieży pokazuje przeciwstawne końce continuum, w jakich odbywa się ten proces transformacji. Jednakże prowadząc badania mlodzieży na przestrzeni kilkunastu lat dostrzega zlożoność problemu i jest daleki od formulowania jednoznacznych sadów. Dostrzegajacc problem, osadzając go w szerokim kontekście socjologii światowej zostawia zawsze ten moment do refleksji czytelnikowi, a chyba i samemu sobie. W jednej z książek pisze: Dokonane skrótowo omówienie wyników badań socjologicznych na temat wartości moralnych mlodzieży i doroslych obejmuje głównie polowę lat dziewięćdziesiatych $i w$ tym sensie zyskuje już pewnego stopnia walor historyczny. Mamy tu do czynienia ze znanym zjawiskiem dysharmonii pomiędzy szybko zmieniajacymi się realiami zycia a ich naukowym opisem ${ }^{37}$.

Bogactwo wiedzy w analizowanym zakresie pozwala Autorowi na swobodne poruszanie się w problematyce systemu wartości wspólczesnej młodzieży. Przy czym już dość wcześnie zauważył narastanie problemów związanych $\mathrm{z}$ analizą systemu wartości młodzieży, dostrzegając istnienie w nim rozbieżnych cech. Już w 1991 r. pisal, że część mlodych katolików polskich znajduje się w sytuacji dysonansowo-stresowej. Nie ma zgodności pomiędzy osobiście uznawanym systemem wartości a systemem wartości wynikajqcym z wiary propagowanej przez religię. Część katolików żyje wedlug norm i regut, które nie maja usprawiedliwienia (legitymizacji) w Kościele. Rozbieżność między systemem wartości upowszechniajacym się $w$ spoleczenstwie a systemem wartości zwiqzanych z wiara jest znaczna ${ }^{38}$.

Tę diagnozę z 1991 r. ks. Profesor regularnie weryfikuje, przede wszystkim opierając swoje konstatacje na wlasnych badaniach empirycznych. Pokazuje w nich jak ważną rolę w okresie dokonującej się transformacji spolecznej ma znajomość procesów zmiany systemu wartości najmlodszego pokolenia. W monografii poświęconej sensowi życia mlodzieży szkolnej, wydanej w 1998 r., napisal: W warunkach radykalnych zmian spolecznych problemy mlodzieży ujawniaja ukryte lub przyszle problemy calego spoleczeństwa (mlodzież jako nośnik i barometr przemian). Sama młodzież znajduje się $w$ fazie intensywnego odkrywania wlasnego »ja《, konstruowania planów życiowych, poszukiwania czegoś nowego, alternatywnego wobec zastanej rzeczywistości, kwestionowania celów i wartości

\footnotetext{
${ }^{36}$ Por tamże, s. 118

${ }^{37}$ J. Mari ań s ki: Kryzys..., dz. cyt., s. 422-423.

${ }^{38}$ J. Mariański, W. Zdaniewi c z: Wartości religijne i moralne mlodych Polaków. Warszawa 1991 s. 10
} 
uznawanych przez doroslych. Poszukujac sensu życia, spotyka się ona z wieloma różnymi odpowiedziami w zakresie problemów egzystencjalnych ${ }^{39}$. Efektem tych poszukiwań jest pojawienie się nowych czynników w ich systemie wartości, dość często odleglych od wartości ich rodziców.

Badając kierunek zmian w swoich propozycjach ks. Profesor unika jednoznaczności, sugerując raczej, że mamy raczej do czynienia z ,gorącym tyglem". $W$ spoleczenstwie polskim lat dziewięćdziesiatych można byto obserwować przemiany $w$ dziedzinie wartości norm moralnych (...). Empirycznie trudno jednak je określić i wymierzyć, zwłaszcza w skali globalnej. Proporcje tych procesów ksztaltowaty się rozmaicie $w$ poszczególnych środowiskach spolecznych $i$ w odniesieniu do rozmaitych rodzajów i form moralności. Szczególowe opisanie przemian wartości moralnych poprzez precyzyjne wskaźniki empiryczne nie jest sprawq latwa, występowanie zaś ze zbyt prostymi diagnozami nie byloby wskazane. Należy, więc raczej skoncentrować się na analizie teraźniejszości jako rzeczywistości »sui generis« niż rozstrzygać o kierunku transformacji »do" jako procesie linearnym, nawet jeżeli rzeczywiście »jutro« zaczyna się już »dzisiaj«, a "wychylanie się k ku przysztości ksztaltuje się tu i teraz ${ }^{40}$.

Wszelkie stawianie hipotez może być obarczone subiektywizmem. Stąd wedlug ks. Janusza Mariańskiego namnożyło się wiele hipotez na temat praktyk religijnych wspólczesnego spoleczeństwa. Wedlug jednej z nich utrzymuje się na względnie stalym poziomie stan praktyk religijnych, zwlaszcza niedzielnych; wedlug drugiej - mamy do czynienia z nieznacznymi wahaniami poziomu uczestnictwa $w$ kulcie religijnym; wedlug trzeciej - następuje wyrażne przesunięcie od kategorii praktykujacych regularnie do praktykujqcych nieregularnie; wedlug czwartej - następuje polaryzacja w sferze praktyk religijnych, wzrasta odsetek praktykujacych w każda niedziele i równocześnie w tym samym stopniu wzrasta odsetek tych, którzy przestali praktykować; wedlug piatej - następuje wyraźny spadek realizowanych praktyk religijnych, zwlaszcza takich jak udzial w niedzielnej mszy św. i spowiedzi wielkanocnej ${ }^{41}$.

Opisywane przez siebie zjawiska postrzega bez zbędnego wartościowania. Wychodzi z założenia, że tworzeniem się nowych wartości jest charakterystycznym symptomem dla kultury prefiguratywnej. Waga jego konstatacji jest ogromna a mieści się $\mathrm{w}$ określeniu $\mathrm{w}$ jakim przedziale mieszczą się interesujace go procesy, pisze np., że sens życia mlodzieży daje się określić w ramach „między nadzieją a zwatpieniem". $Z$ jednej strony, pisze, że mlodzież wykazuje też więk-

${ }^{39}$ J. Ma ri ań s ki: Między nadzieja..., dz. cyt., s. 7.

${ }^{40}$ J. Mari ań ski: Kryzys..., dz. cyt., s. 423.

${ }^{41}$ J. Mari iń s ki: Religijność w zmieniajacym się spoleczeństwie polskim. W: Katolicyzm polski na przelomie wieków. Mity, rzeczywistość, obawy, nadzieje. Red. J. B a n i a k. Poznań 2001 s. 213. 
szą sklonność do tego, co można nazwać „transcendentną bezdomnością"42. Dostrzega również narastające grono mlodych umiejących pozytywnie określać swój status w przyszlości. W końcowych konkluzjach książki dotyczącej sensu życia młodziėży możemy przeczytać, że oprócz wielu zniechęconych, zdystansowanych, nieaktywnych, wylaczonych z życia publicznego, pesymistycznie postrzegajacych szanse realizacji swoich zamierzen życiowych, wydaje się narastac krag ludzi aktywnych, nastawionych innowacyjnie do życia, o wydlużonym horyzoncie planowania życiowego, przekonanych o szansach realizacji zamierzonych celów $i$ szeroko rozumianej samorealizacji, o dużym potencjale przedsiębiorczości ${ }^{43}$.

Podejmowany przez Autora opis wartości odnoszących się do wspólczesnego społeczeństwa i świadomości mlodzieży jest ważny $\mathrm{z}$ wielu powodów. Zrealizowane badania pozwalaja empirycznie zweryfikować pewne tezy, które funkcjonują w świadomości socjologów niejako a priori. Tu otrzymujemy material oparty na rzetelnych badaniach. Opisywane przez Autora zjawiska nie są oparte na wartościujących sądach. Wszak jedni opisują świadomość młodzieży w kategoriach optymistycznych, inni pesymistycznych. Jak pisze sam Autor pesymizm lub optymizm to kategorie malo poznawcze, bardziej natury emocjonalnej ${ }^{44}$.

Ważne jest również podejście Autora: analiza w czasie i traktowanie problemu jako coś, co trwa i nie jest zakończone. W zakończeniu cytowanej wyżej pracy czytamy, że mamy do czynienia ze zmiana, ale też i z elementami trwalości i nowym sposobem wartościowania tego, co wiąże się z malżeństwem i rodzina. Nie jesteśmy świadkami radykalnego przelomu spoleczno-moralnego $w$ życiu rodzinnym. To, co »stare (tradycyjna rodzina katolicka), obowiqzuje jeszcze w wielu obszarach, ale to, co »nowe" (moralność zsekularyzowana, zindywidualizowana, ponowoczesna), zaczyna także być już coraz bardziej widoczne na wielu plaszczyznach życia codziennego ${ }^{45}$.

Kolejna cecha w podejściu do analizowanych zagadnień to calościowe podejście do problemu, wielopoziomowa próba poszukiwania przyczyn opisywanych zjawisk oraz dążenie do formulowania prognozy analizowanych zjawisk. Przy czym ten ostatni wymiar Autor stawia prowokacyjnie w postaci postawienia sobie i odbiorcy wielu watpliwości. Jednoznacznie wskazuje jedynie, jak je rozwiązuje wspólczesna socjologia. Jednocześnie dostrzega to, na ile te odpowiedzi są adekwatne do polskiego spoleczeństwa.

\footnotetext{
${ }^{42}$ Por. J. Mari a ń s k i: Co mówi „duch czasu” - sekularyzacja religii i spoleczeństwo postsekularne. „Roczniki Nauk Społecznych KUL”. T. 32: 2004 z. 1 s. 69.

${ }^{43}$ J. Ma ri ań s ki: Między nadzieja..., dz. cyt., s. 355.

${ }^{44}$ Por. tamże, s. 484

${ }^{45}$ Tamże, s. 485.
} 
Analizowane przez ks. Prof. Janusza Mariańskiego problemy sa niezwykle ważne w kontekście bieżącego życia spolecznego. Wiedza o opisywanych zjawiskach jest niezwykle ważna dla osób zajmujących się modelowaniem procesów spolecznych. Jest to również cenny drogowskaz dla kościelnych hierarchów i duchowieństwa, wszak opisywane przez Autora zjawiska pokazuja, że Kościół i propagowane przez niego wzorce $\mathrm{i}$ wartości $\mathrm{w}$ wielu wypadkach są marginalizowane. Wynika to $z$ faktu istnienia pluralizmu religijnego. W tej nowej sytuacji tworzy się zjawisko religijnego rynku. Jak pisal P.L. Berger: Sytuacja pluralistyczna jest przede wszystkim sytuacja rynkowa - instytucje religijne stajq się agencjami rynkowymi, a tradycje religijne - artykulami konsumpcyjnymi. W każdym razie poważna czessć aktywności religijnej w tej sytuacji zostaje zdominowana przez logikę ekonomiki rynkowej ${ }^{46}$. Na nowe sytuacje zarówno Kościół, jak i inne instytucje zajmujace się modelowaniem i upowszechnianiem pożądanych spolecznie wzorców powinny posiadać nowe strategie.

${ }^{46}$ P. L. B e rg e r: Święty baldachim. Elementy socjologiczne teorii religii. Kraków $1997 \mathrm{~s}$. 186 
